\title{
Policy on Developing University Lecturers in Some Developed Countries in the World and the Experience Lessons for Vietnam
}

\author{
Guandong Song \\ Institute of Education Economy and Management \\ Northeastern University \\ Shenyang, China 110819
}

\author{
Van Huy Thang \\ Institute of Education Economy and Management \\ Northeastern University \\ Shenyang, China 110819
}

\author{
Thi Hoang Anh Le \\ Master of Business Administration \\ Northeastern University \\ Shenyang, China 110819
}

\begin{abstract}
In the context of today's trend of comprehensive international integration, developing universities in line with their lecturers is an indispensable and objective task. For the appropriate implementation of university lecturers' great mission, the State has to build and complete policies on developing the lecturers, creating a legal environment and the most favorable conditions for their development in quantity, quality and ratio, structure. From the experience lessons of the countries: United State, Singapore, China, Japan, etc. useful lessons for completing policies on university lecturer development in Vietnam shall be drawn so that it is suitable to Vietnam's conditions.
\end{abstract}

Keywords-policy on developing lecturers; university lecturers; Vietnam

\section{INTRODUCTION}

The State has to pay attention to invest in national development, considering education as its leading national guideline through practical, specific policies. The similar feature of developed countries is their profound perception: Among all the resources of economic development, human resource always plays the key role to all the economic performances, especially in the context that science becomes a direct producing force thanks to the dramatic development in modern technologies and sciences, the intelligence content in each product is increasingly higher so that universities lectures hold the main role in the developing progress. Completing policies on lecturer development for adequate quantity, quality and ratio is a vital requirement.

\section{POLICIES ON DEVELOPING UNIVERSITY LECTURERS IN SOME DEVELOPED COUNTRIES IN THE WORLD}

\section{A. Policy on Planning Lecturers}

In 1964, Taiwan established a National Institution for human resource development with the task of supporting their Government to build a national human resource planning. Since 1966, based on periodical development demands, the institution proposed a "Plan for human resource development" every year. Based on that, they performed the plan's investigation, coordination. The lesson drawn out of Taiwan is the mechanism regulating its national human resource with a "continuous-in-long-terms" guideline. Human resource is a special factor which needs uninterrupted training and improvement.

In United State, besides the strategy of education and training development, the strategy of the sector's human resource and the investments in science and technology and as well as the policies on attracting proficient persons and facilitating the country's professors and scientists are the three significant factors to create foundation for bringing the lecturer's role and advantages into play, promoting them to the top position in the world.

Singapore's strategy is to link to Western universities, attracting, employing foreign lecturers, using English as the main teaching language, thoroughly reproducing Western's organization and management, planning their universities and human resource as assuring an appropriate proportion to the development scale of university training.

\section{B. Policy on Attracting, Recruiting Lecturers}

1) Attracting policy: United State's funding for education and training always accounts for $13.72 \%$ of its Gross Domestic Product in comparison with $4 \%$ of the 
world. Their policy on building a leading training system in the world, the belief in social obligation and the open culture, the creative environment, the adequate condition of facilities are the main reasons for the participation of talented people in the world. Many states in United State has built financial assistance systems that enable the districts to pay salary, create job opportunities and entitle proficient people in other sectors the discretion to work as a lecturer.

Texas (United State) has promulgated a series of policies to attract outstanding persons to education: Promoting "Teach for Texas" scholarship programs and creating more financial opportunities, aid programs for lecturers in order to attract prominent individuals to education, providing candidates with favorable conditions to apply to universities for lecturer post. Besides, the system consultancy programs for new lecturers to improve their ability have been launched.

President Obama once said: Recruiting a new teacher generation, paying more for proficient ones, putting the bad ones out of the class. US' Center for the Study of Teaching and Policy determines these policies as located in the system of attracting, recruiting and retaining qualified staffs in the sector; building encouragement policy and appropriate conditions to support the lecturer's tasks.

Singapore's Government, Ministry of Education and its universities have a variety of preferential policy, mechanism which are inclusively implemented aiming to provide the best working environment, respect, belief, facilities for living activities and transportation, material and spiritual life, chances for vocational promotion, research opportunities, researching institutions, high quality universities, proficient colleagues to the foreign lecturers demanding to work there. The country's policy on attracting senior lecturers is mostly similar to the US's one: proper, methodical with a high profession. First, they set the target of attracting talents and then specific assignments shall be implemented.

Since the middle of the 1990s, China has applied international assessment methods in their recruitment and promotion: the positions, jobs have been publicly advertized and scholars could require promotions and rewards based on their achievement. Thanks to many preferential policies, over $80 \%$ overseas students have come back after their graduation. Currently, China has changed their opinion that proficient people could not come back to the hometown for working but to live, work in their host country, serving China through part-time works or their competence and investment.

2) Recruiting policy: In American universities, the power primarily belongs to Faculties. The recruiting procedure is public, transparent and based on explicit targets and standards that scientific target holds the most priority. Competent and prestigious professors have the decision making authority, students have right to participate and present their opinion. If being recruited, the candidate shall work in a probationary period in certain years, normally as an assistant professor. In the period's end, lecturer's profile shall be reviewed by an internal independent counsel and an outside one, the decision shall be drawn through a ballot. In case of acceptance, the lecturer shall be admitted to the university with a permanent contract but it does not mean a perpetual status.

In 1998, Singapore founded a Committee for talent recruitment, building its recruiting policy based on the ability to contribute to the country's development without discrimination of nationality, race, gender or degree. All the information and policies are publicized, transparent. The combination of knowledge, experience, style in researching, training, cooperating in many sectors has been contributing to promote the domestic lecturers' quality.

The recruitment procedure in Korea is transparently implemented in fair competitions under the control of the central human resource management institution (Ministry of Public Administration and Security) through a centralized recruiting organization. The projects "Korean intelligence 2005-2012", "University stars" has been launched aiming to improve Korea's teaching and researching capacity for the country to have at least 5 top universities in the world. In addition, about 50 "star-professors" are recruited to work in talent programs.

\section{Using and Assessing Policy}

The features of United States' university training are its mobility that lecturers, students could easily change their school; competition that looking for the best students, the most proficient lecturers with funding for the university's research and position; academic freedom: lecturers and learners have academic freedom to perform researches that state the academic or social problems without pressure or prejudice; stability: despite many changes in the nature of lecturer appointment and academic performance organization, most the lectures are appointed as full-time employees that brings them the vocational security, the assurance of academic freedom and a good living standard in the society.

US's education tends toward the learners: most universities in US focus on their students, considering them as service customers need to be cared, served better. US highly regards the personal responsibilities of lectures in teaching and realizes its through detailed regulation. In a dynamic society, having a permanent job is a special preference that makes lecturer post in universities become relatively attractive though the income is lower than that of persons, with the similar qualification, who work for large firms or corporations.

The internal structure of American universities is different to European education systems': "each sector has only one professor", the universities in US normally find a way to establish large faculties, transferring the universities' leadership power to its faculties.

In United States, lecturers' working time is normally allocated into three parts: teaching, scientific research and service performance. The ratio is: $40-40-20$, for reputable universities it is 30-60-10, for small ones, it is 60-20-20.

Korea government uses three means to control, assess the quality: developing standard set to recognize universities and curricula; using achievement targets in training for funding 
universities; the Government and science and technology sector perform investments and use it as the standard for funding universities.

Today, China has been actively utilizing their human resource based on the explicit mechanism of "three stages": The first stage is input (recruitment, appointment); The second is usage (award granting, discipline performance, assignment); The third is output with the strict supervision of three-party trade cooperation mechanism to resolve basic problems. For lecturers who are admitted with a contemporary contract, a consideration and examination shall be implemented upon the contract's expiration for drawing the decision to enter into a permanent contract or not. Most of the posts, scientific positions and management positions are performed based on contracts with a defined term and through a competition. In addition, a whole-life working assurance is granted to excellent professors. Based on an annual lecturers consideration, inappropriate ones shall have their retirement performed before the terms or be assigned to another position. Moreover, there is a policy to assign universities to allocate the management to their faculties and professional teams so that they have higher discretion in recruiting, developing and assessing the lectures. Besides, the reforming of the national budget has provided each faculty and professional teams with a chance to approach and directly use the funding.

Singapore, through its development periods of the national education system, has set the quality requirement that lecturers and education leadership shall have appropriate qualification and management ability. In the beginning period, Singaporean universities disbursed a lot of money to recruit proficient managers for management. Then they appointed qualified persons and transferred all the tasks to the successors.

\section{Training Policy}

According to the Federal Law of United States, training is defined as a process of continuous implementation that enhances individual and organizational competencies. Preservice teachers can be trained as soon as they apply for a teaching position, and this training policy has made an appeal to talents all over the world for teaching and research in the United States.

At prestigious universities of United States, only onethird of the teaching time is provided by the university's lecturers, another one-third is provided by competent lecturers invited from other local universities, the other is provided by foreign professors. A general policy for university lecturers is that for those who have taught 4 or 5 years, they can take a one-year leave to attend to a refresher course ( entirely depending on personal options, it can be at any school or institute, domestic or international). This leave mode for researching is called sabbatical mode.

Lecturers can apply for a temporary leave for training, field trips or unpaid leave to study or prepare for rank promotion. One of the basics for developing training plans for lecturers is the meeting and discussion between the lecturers and the trainer.
The Chinese government has implemented actively policies in which high-quality lecturers are selected to study abroad, through the National Scholarship Fund, and shortterm traineeship programs. This is considered as a new breakthrough in China's policy on improving the international quality and competitiveness of human resources. Management and professional development of the teaching staff are carried out annually through the system of training and certification with different levels of professional qualifications.

One of the great characteristics of the educational development process in Japan is that well-prepared educational development policies have been developed through councils, high-level consultancy committees and institutionalized by laws, the system of legal documents on education management. In addition to the basic provisions related to education which set out in the Constitution, a wide spectrum of detailed laws has also been issued to organize and manage educational activities and systems

\section{E. Compensation and Benefits Policy}

1) Compensation Policy:In terms of GDP, the US education budget has increased steadily. In 1960, the percentage of the budget was 5.3\% of GDP, in 1991 it was $7 \%$ and now it is approximately $7.5 \%$ of GDP. The budget has focused on a considerable part of the training. Research funds from US Department of Education and US National Science Foundation, as well as philanthropic programs, regularly spend a large portion of their budget to support financially for professors.

The pay rise has been based on annual performance which is also applied to lecturers researching, teaching, and engaging in more productive work. In addition, deans and principals have their own fund to increase their salary, to a certain extent. They often use this fund to raise salaries for high-performing teachers.

Likewise, the UK has also followed performance-related pay policy and this approach is implemented through the assessment of direct managers and annual reports on outputs, ability and communication skills.

The Singapore government has had flexible policies, expressed in four principles of compensation policy: having flexible salary system, appropriating to economic conditions; trying to keep up with market volatility; having bonuses and having a pay rise based on achievements; the method of pay has to be specific and obvious.

China has reformed the salary systems for intellectuals, faculty members related to completed tasks and performances. Several world-renowned scientists invited to work in the country have got a high pay equivalent to the salary they received abroad, provided housing, working facilities, and assistance. Moreover, working position is not life-long but it is contractual and evaluated annually. The salary of lecturers consists of 3 parts: basic salary based on the level of education; responsibility to rank depending on current position and scientific title; job benefits includes 
bonuses, percentages from research funding or research contracts. The salary increases every two years.

2) Benefits policy:Japan has carried out a salary systems making the employees proud of his or her position and devote to working, not take advantage of his position for profit, if he violates professional ethics, he will lose his job for the rest of his life. Every year, Japan has still conducted classification assessments for appropriate remuneration, appointed and reappointed titles. All university lecturers are honored as "Sir/Madam," a title that reflects the respect of Japanese society for highly-educated people. The high demand for the lecturers is that they have to always be towards the improvement and enhancement of personal prestige in teaching and social activities.

Singapore has had a coherent policy for a purpose of supporting the belief that teachers are always in a high position, receive a top salary; besides, the aspiration for being dedicated, respected and honored is absolutely high. Comprehensive benefits policies have been concentrated, including salary, fully comprehensive health insurance benefits, vacation benefits, career development opportunities, working in a flexible time aiming at helping trainees gain work-life balance.

The US education system is also undoubtedly noteworthy, academic titles are explicitly classified, that foreigners are appointed to academic positions is very different from many countries. The bonus policy has been implemented for highquality lecturers and universities with achievements in improving the quality of training. At the end of every semester, that students evaluate lecturers is publicly announced at the beginning of each semester, and the title of faculty members: excellence, elite is awarded by students' nomination and election.

\section{EXPERIENCE LESSONS FOR POLICIES ON DEVELOPING UNIVERSITY LECTURERS IN VIETNAM}

First, developed countries have implemented a policy on reorganizing the number of teaching staff in accordance with governing body's plans and the national strategy on human resources development. On the basis of accurately forecasting the demand for human resources enhancing national development, which follows the set objectives and scientific vision, with the tasks and possible solutions. In general, several countries have shown concern for developing human resources aiming to ensure that they are not insufficient and have continuity and inheritance. New recruits are adjusted regularly to guarantee continuity between ages, with reviews for retirees and additional vacancies. Personnel planning are also one of the important tasks for faculty use.

Second, the policy on attracting and recruiting lecturers: With a complete legal policy system, the economy and society are highly developed, the investment budget for education and training is satisfactory, every country has a foundation for a democratic working environment, creative freedom, and the promotion of talent. With modern facilities and equipment, reasonable income, meeting material and spiritual needs, promotion opportunities, housing regime ... It is undeniable that policies on attracting lecturers have been remarkably successful.

The policy on recruitment is on a large scale: lecturers having the academic title of Doctor or higher qualified for the provided position, regardless of nationality, recruitment is conducted year-round and directly by faculty members of the recruitment subject openly and transparently.

Third, the policy on utilizing and assessing teaching staff at universities of all countries concretizes regulations in detail on functions and tasks of lecturers based on their positions. Workforce Reduction Policy is implemented, which increases contracting; therefore, competitiveness of employment positions is fierce, which generates motivation for development. Empowering the administration rights, using lecturers for the subject groups, maximizing the ability of the lecturers and students evaluate lecturers through the quality and efficiency of the learners.

Policies on management and utilization of faculty in several industrialized countries have been considered as factors stimulating quantitative and qualitative growth, and providing new motivation for faculty. Typically, these policies are integrated into social policies such as employment policies, salary policies, and social welfare policies.

Fourth, the training policies apply immediately to the post-recruitment candidates. After 4-5 years of teaching, the lecturers can have an internship or take a field trip, in 1 year. The policy on collaborating training among countries, universities, and sub-sectors encourages faculty to be more dynamic and develop expertise, foreign languages, communication skill... Policies on encouragement, rewarding self-study, and lifelong training lecturers have to be implemented.

Fifth, the policy on compensation in most countries is paying salary related to performance, not to seniority (except Japan). Principals and dean have their own salary fund to give a pay rise for the lecturers completing their tasks in an excellent manner. There is a wide discrepancy in the salary levels of master's degree - Ph.D. - associate professor professor. The reward system in terms of both material and spiritual value is reasonable.

\section{CONCLUSION}

The attraction, utilization, and reward of talents as university lecturers through the Party's guidelines and policies must be formulated into a sustainable strategy by the State, through appropriate mechanisms and policies, the faculty is able to contribute to the education and training of our country. The lessons learned from developed countries around the world will be useful for the Vietnamese Government; hence, the Government implements comprehensive solutions to improve the policy on developing university lecturers. 


\section{REFERENCES}

[1] Nguyen Ba Can, Improving the policy of higher education development in Vietnam today, National Economics University, 2009.

[2] Do Minh Cuong, Vietnam's Human Resources Development for Higher Education, National Political Publishing House, Hanoi, 2010.

[3] Vu Ngoc Hai, The breakthrough solutions of fundamental and comprehensive reform of education in Vietnam, The Vietnam Institute of Educational Sciences, 2012.

[4] Nguyen Huu Hai, Understanding US Public Administration: Theory and Practice, National Political Publishing House, Hanoi, 2013.

[5] Vietnam National Council for Education, Higher Education Reform, and International Integration, Educational Publishing House, Hanoi, 2005. 